\title{
Analysis of the intratesticular control of spermatogenesis by ex-vivo approaching
}

\author{
Marie-Hélene Perrard ${ }^{1}$, Nadia Prisant ${ }^{2}$, Cendrine Geoffroy-Siraudin 3 , \\ Dominique Segretain ${ }^{2}$, Georges Pointis ${ }^{2}$, Marie-Roberte Guichaoua ${ }^{3}$, \\ Philippe Durand ${ }^{1}$
}

\author{
${ }^{1}$ Institut de Génomique Fonctionnelle de Lyon, Université de Lyon, Université Lyon I; CNRS; INRA; \\ Ecole Normale Supérieure de Lyon, Lyon, France \\ 2INSERM U 895, Team 5 "Physiopathology of germ cell control: genomic and non genomic mechanisms" \\ C3M, Nice and Université de Paris Descartes, Paris, France \\ ${ }^{3}$ Laboratoire de Biologie de la Reproduction, Hôpital de la Conception, Baille Marseille, France
}

\begin{abstract}
Spermatogenesis involves the realization of a particular genetic program which requires a specific environment ("niche"). Multiplication, differentiation and apoptosis of male germ cells are finely regulated by pituitary hormones (mainly LH and FSH), and by a complex network of factors originating from both the somatic cells and the germ cells of the testis. It is becoming clear that hormones and intra-testicular regulatory factors can compensate, at least in part, for the absence of some hormones or factors including FSH and LH or androgen receptors. Since, most of the growth factors, cytokines and neurotrophins produced within the testis are widely expressed in the organism, the attempts to understand their role in spermatogenesis by "classical" knock-out strategies have been often disappointing. Therefore an important aspect of our previous work was to settle and characterize carefully two systems of cocultures of testicular germ cells with somatic cells in bicameral chambers. For instance, we showed for the first time that the whole meiotic step could be performed in vitro in a mammalian species (the rat). Moreover, all our data indicate that our co-culture systems enable to highlight mechanisms pertinent to the physiological processes. Sperm parameters have been deteriorated considerably during the past 4-5 decades. There is now evidence that chemical exposure is at least partly responsible for these testicular diseases. If a large number of environmental pollutants are able to affect male fertility and to exert carcinogenic effects, their cellular and molecular mechanisms are still unidentified. The cultures in bicameral chambers that we settled can be used to study the effects of a toxicant when added in the basal compartment of the culture chamber, which appears relevant to the in vivo situation. Taken together our results indicate that our in vitro culture systems, which allow screening for the effect of biological activity of different physiological factors, can be also helpful to study that of any chemicals on both survival and multiplication/differentiation of somatic and/or spermatogenic cells on a relatively long time period.
\end{abstract}

Key words: spermatogenesis, germ cell culture, testicular regulations, testicular toxicology

\section{Introduction}

Spermatogenesis involves the realization of a particular genetic program that requires a specific environment ("niche"). Multiplication, differentiation and apoptosis of male germ cells are finely regulated by pituitary hormones, mainly LH and FSH [1], and by a

Correspondance: P. Durand, Institut de Génomique Fonctionnelle de Lyon Université de Lyon, Université Lyon 1, CNRS, INRA, Ecole Normale Supérieure de Lyon, 46 allée d'Italie, 69364 Lyon Cedex 07, France; tel.(+33 (0)4 7272 89-65); fax. (+33 (0)4 727289 92), e-mail: philippe.durand@ens-lyon.fr complex network of factors originating from both the somatic cells and the germ cells of the testis [2], as well as by direct communications between supporting somatic Sertoli cells and germ cells [3].

It is becoming clear that hormones and intra-testicular regulatory factors can compensate, at least in part, for the absence of some hormones or factors including FSH [4-6] and androgen [7-10], or luteinizing hormone [11] receptors. Since most of the factors produced within the testis are also widely expressed in other organs, the attempts to understand their role in spermatogenesis by conventional knockout (KO) strategies have been limited. Some mice die shortly 


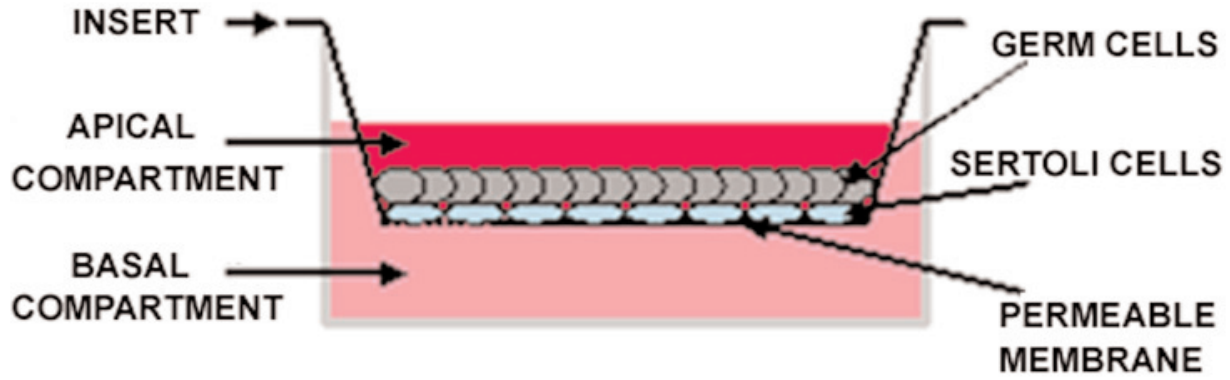

Fig. 1. Culture system of germ cells together with Sertoli cells, in bicameral chambers. after birth (e.g. KO of insulin-like growth factor-I, IGF-I, [12]; transforming growth factor $\beta$ (TGF- $\beta$ ) [13]; nerve growth factor (NGF) [14], or they do not exhibit any particular phenotype on male fertility (e.g. KO of IGF-II, IGF-binding protein-2 to -6 (IGFBP-2 to -6) [15]. Moreover, even if for some of these factors produced by, and acting on, testicular cells, KO models or spontaneous genetic defects have allowed to understand their role on the early steps of spermatogenesis (e.g. stem cell factor (SCF) [16], Glial cell linederived neurotrophic factor (GDNF) [17], their action, if any, on later steps of spermatogenesis could not be studied since invalidation of these genes results in an early blockade of the spermatogenic process. In addition, ubiquitous factors (such as IGF-I, TGF- $\beta$ ) may be expressed by several cell types in the testis and their role can change during development and spermatogenesis [18].

\section{Physiological studies in ex-vivo models}

Therefore, an important aspect of our work, over the past twelve years, was to settle and characterize carefully two systems of co-cultures of testicular germ cells with somatic cells in bicameral chambers (Fig.1), in a defined culture medium, which maintain the blood testis barrier (Figs. 2, 3) and enable to study the regulations involved in the mitotic phase and the meiotic phase of spermatogenesis, and the early steps of spermiogenesis over a 4-week culture period in the rat. In the first system, elutriated spermatogonia/early spermatocytes, pachytene spermatocytes or round spermatids are cultured on a monolayer of Sertoli cells, whereas in the other system, small pieces of seminiferous tubule segments are seeded [19-21]. In these systems, it is indeed possible to study: 1) the physiology of the blood-testis barrier; 2) survival / death of somatic and/or germ cells, proliferation of Sertoli cells and spermatogonia; 3 ) the course of meiotic divisions (key stage of spermatogenesis during which genetic recombinations occur); 4) the cytogenetic features of germ cells; 5) the expression of specific genes in the germ cells or Sertoli cells; 6) the peptide profiling of the culture supernatant/cultured cells.
An important aspect of the results obtained using in vitro/ex-vivo models is their relevance to the in vivo physiological situation. The germ cell/Sertoli cell coculture systems that we settled [19-21] have been carefully validated from the physiological point of view, on many aspects, over the last twelve years. To our knowledge, there is no other system of culture of male germ cells and Sertoli cells which has been so carefully and extensively validated.

We were the first to show that the whole meiotic process could occur in vitro in a mammal, the rat [22]. This was ascertained by cytological and cytometrical analyses and by the expression of germ cell specific genes. We showed subsequently that the development of the meiotic step, in vitro, in the testis of pubertal rats was close to what happens in vivo when considering the changes in the cell populations of different ploidy, the gene expression of germ cells, the kinetics of differentiation of BrdU-labeled early or middle pachytene spermatocytes and the levels of apoptosis in the different cell populations, even if the rate of in vitro differentiation of BrdU-labeled spermatocytes slowed down when reaching the stage of middle pachytene spermatocyte [23]. More recently, we also demonstrated that there was no significant difference between the percentages of leptotene, zygotene, pachytene, and diplotene stages in 42 day-old rats and on day 16 of culture of testes from 23 day-old rats (Fig. 4), indicating a similar development in vivo and in vitro (Geoffroy-Siraudin et al submitted).

Our findings also showed that FSH and testosterone have positive and somewhat overlapping effects on the meiotic divisions and the post-meiotic expression of a germ cell-specific gene (transition protein1; TP1), effects which cannot be related solely to their ability to reduce germinal cell apoptosis [24].These results have been recently confirmed by others using KO mouse models [8,9,25].

Recently we have reported that NGF and its two receptors are similarly expressed in vivo and under our culture conditions and that both NGF and TGF- $\beta$ are able to regulate negatively the second meiotic division of rat spermatocytes [26, 27]. More recently we have demonstrated that NGF and TGF $\beta$ have a totally 

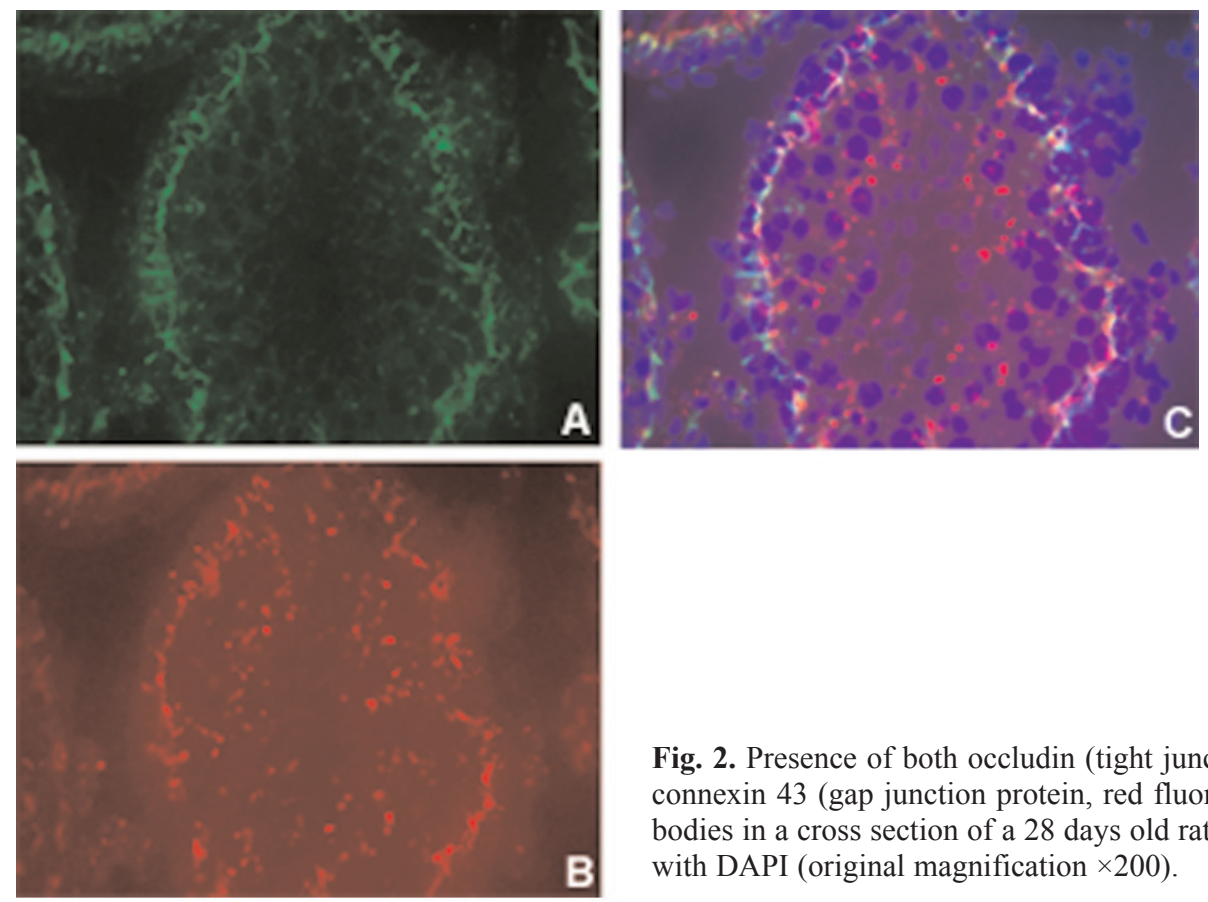

Fig. 2. Presence of both occludin (tight junction protein, green fluorescence) (A) and connexin 43 (gap junction protein, red fluorescence) (B), detected with specific antibodies in a cross section of a 28 days old rat testis. (C) merge; the nuclei were stained with DAPI (original magnification $\times 200$ ).
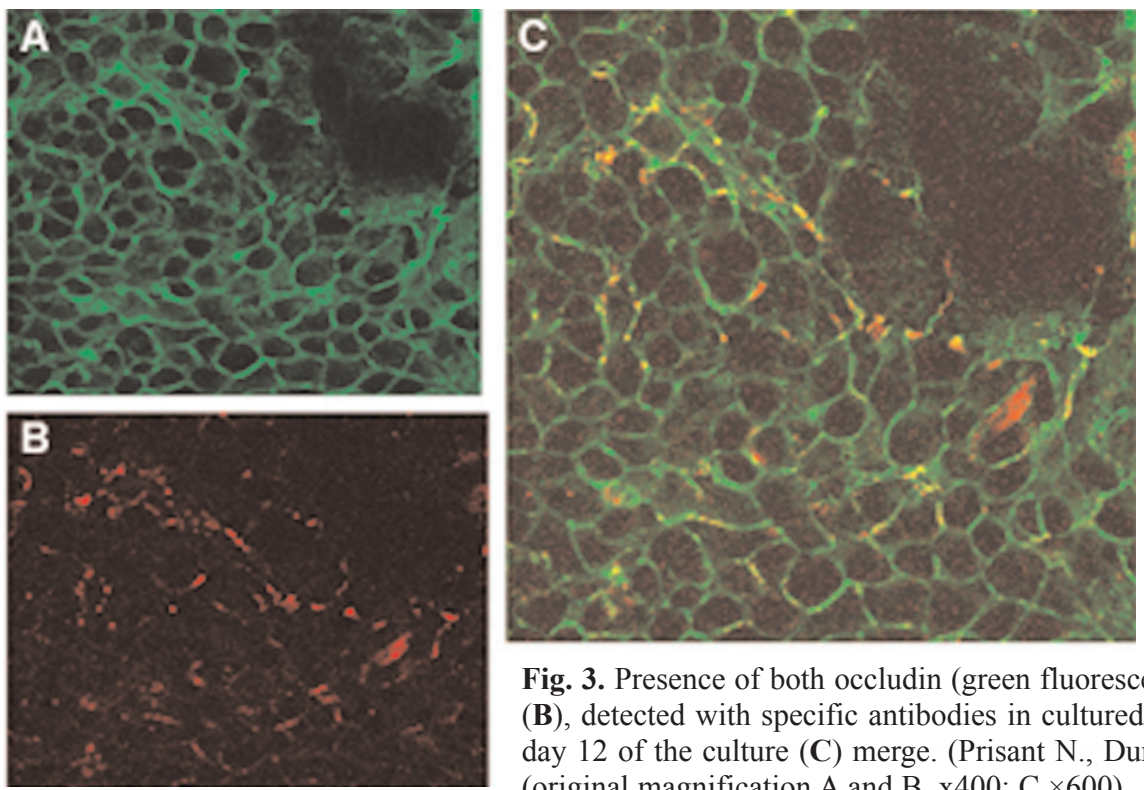

Fig. 3. Presence of both occludin (green fluorescence) (A), and connexin 43 (red fluorescence) (B), detected with specific antibodies in cultured seminiferous tubules from 20days old rats at day 12 of the culture (C) merge. (Prisant N., Durand P. Segretain D., Pointis G. unpublished). (original magnification $\mathrm{A}$ and $\mathrm{B}, \mathrm{x} 400 ; \mathrm{C} \times 600$ ).

redundant (without additivity) effect on this step (Perrard $\mathrm{MH}$ and Durand P 2009 in press). This result offers an explanation to the study of Ingman and Robertson [28], with null mutant mice for TGF- $\beta 1$, claiming that their data conflicted with conclusions from in vitro culture experiments that TGF $\beta 1$ might act to impair spermatocyte progression through the second meiotic division [26]. Indeed, these authors did not observe a change at this level in their mouse model, but it must be emphasized that male gametes synthesize TGF $\beta 1$ with greatest abundance detected in spermatocytes and early round spermatids [29], i.e precisely, the same germ cell types which synthesize $\beta$-NGF [27]. Therefore, it is reasonable to speculate that the absence of effect of TGF $\beta 1 \mathrm{KO}$, reported by these authors, was due to the redundant effect of $\beta$ NGF on that step.

We have shown that in vitro meiotic progression of rat spermatocytes requires mitogen-activated protein kinases of Sertoli cells and close contacts between the germ cells and the Sertoli cells [30]. Now, connexin 43 is detected between spermatocytes and Sertoli cells in our cultures. These results fit with a recent study [31] showing that replacement of connexin 43 by connexin 

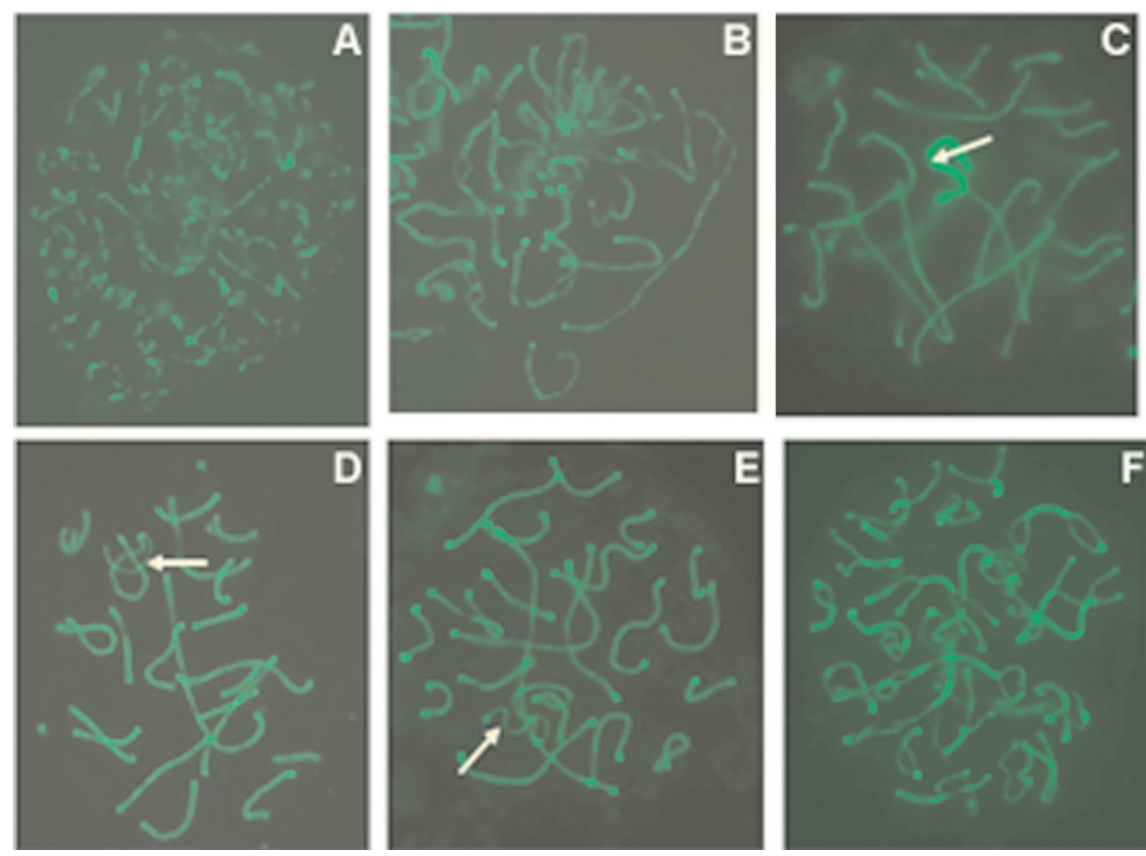

Fig. 4. The different sub-stages of meiotic prophase I in seminiferous tubule cultures: an anti-SCP3 antibody was used to reveal axial elements and lateral elements of synaptonemal complexes. Arrows show different configurations of the sex chromosomes. (a) leptotene spermatocyte; (b) zygotene spermatocyte; (c, d, e) pachytene spermatocyte; (f) diplotene spermatocyte. (Geoffroy-Siraudin C, Durand P, Guichaoua MR unpublished) (original magnification $\times 1000$ ).
26 in transgenic mice impairs spermatogenesis leading to the absence of germ cells beyond spermatocytes type I. Other studies in our laboratory demonstrated that both meiotic divisions are blocked by pharmacological inhibitors of MPF [32], as could be expected [33]. On the mitotic step of spermatogenesis, we have got results consistent with a role of GDNF in inhibiting the S-phase entrance of a large subset of differentiated type A spermatogonia, together with an enhancing effect of the factor on a small population of undifferentiated (stem cells) spermatogonia [34]. Actually, these studies fit quite well with the results of in vivo studies [17,3537]. Further, we have recently shown that $C x 43$ gap junctions between Sertoli cells participate in the control of Sertoli cell proliferation and that $\mathrm{Cx} 43$ gap junctions between Sertoli cells and spermatogonia are indirectly involved in germ cell number increase by controlling germ cell survival rather than germ cell proliferation [38]. Similar results were obtained by the observation of Sertoli cell conditional $\mathrm{Cx} 43 \mathrm{KO}$ mice demonstrating that $\mathrm{Cx} 43$ is essential for control of Sertoli cell proliferation and differentiation $[39,40]$.

Taken together, the above data reinforce the view that our co-culture systems enable to highlight mechanisms pertinent to the physiological processes.

\section{Assessment of toxicological potency of chemicals}

Sperm parameters have been deteriorated considerably during the past 4-5 decades. There is now evidence that chemical exposure is at least partly responsible for these testicular diseases. If a large number of environmental pollutants are able to affect male fertility and to exert carcinogenic effects, their cellular and molecular mechanisms are still unidentified. The cultures in bicameral chambers that we settled should be a major methodological breakthrough in assessing toxicological potency of chemical compounds on a relatively long time period and enabling the study of many aspects of their mechanism of action while reducing the number of animals needed. In these culture systems, testicular germ cells from one rat allow to perform ten to twenty different assays. It is noteworthy that our systems of culture in bicameral chamber allow studying the effects of a toxic substance added to the basal compartment of the culture chamber, and thus mimic what could happen in vivo in the testis. Indeed, the cellular junctions, between Sertoli cells and between Sertoli cells and germ cells, which are essential for spermatogenesis, are maintained or rebuilt in our systems of culture (see above). Therefore, before reaching the germ cells, in our systems, the toxic compounds must cross the barrier structured by Sertoli cells (principal component the blood-testis barrier). By contrast, in "conventional" cultures wells, a compound may be toxic to differentiated germ cells because it is placed directly in contact with these cells, whereas in vivo, it may not have access to the compartment of the seminiferous tubules where this population of germ cells is located. Furthermore, our cultures can be analyzed by cell physiology, cytology, biochemical and molecular biological approaches allowing the determination of the mechanisms responsible for the gonadal toxicity or carcinogenic effect of organic or mineral compounds and of nanoparticles. It should be emphasized that knowledge of the mode of action of the molecules studied can help to determine whether the obser- 
vations made in animals are transferable to humans, which remains a major problem in this type of study.

Our co-culture systems can also serve as an original tool for rapid screening of molecules for therapeutic purposes in order to improve a failing male fertility. The use of a cell population exposed (lot) or not (control group) to the substance allows to get rid of much of the variability between animals that are encountered in testing in vivo and to optimize the power of the tests. In addition, the possibility of rather long term cultures of the cells will allow, most often, testing for the reversibility of the observed effects. Recently, we compared cultures of normal, and irradiated by gamma rays, germ cells. In spermatocytes for non-irradiated cultures, the comet assay revealed the presence of breaks of DNA, whose number decreased during the culture, indicating the involvement of mechanisms of DNA repair associated with meiotic recombination. In irradiated cells, the development of DNA strand breaks was heavily modified. Thus, our model is able to detect genotoxic lesions and / or abnormal DNA repairing [41].

By using these cultures, we have observed that chromium at low concentrations $(1 \mu \mathrm{g} / \mathrm{L})$ severely alters the synaptonemal complexes of the meiotic cells, and decreases by $40 \%$ the number of round spermatids formed in culture (Geoffroy-Siraudin et al submitted).

Taken together these results indicate that our in vitro culture systems, which allow screening for the effect of biological activity of different physiological factors, can be also helpful to study that of any chemicals (either alone or in combination with others) on both survival and multiplication/differentiation of somatic and/or spermatogenic cells on a relatively long time period.

\section{References}

[1] McLachlan RI, O'Donnell L, Meachem SJ, Stanton PG, de Kretser DM, Pratis K, Robertson DM. Identification of specific sites of hormonal regulation in spermatogenesis in rats, monkeys, and man. Recent Prog. Horm. Res. 2002;57:149-79.

[2] Huleihel M, Lunenfeld E. Regulation of spermatogenesis by paracrine/autocrine testicular factors. Asian J. Androl. 2004:6:259-68.

[ 3] Pointis G, Segretain D. Role of connexin-based gap junction channels in testis. Trends Endocrinol. Metab. 2005;16:300-6.

[ 4] Abel MH, Wootton AN, Wilkins V, Huhtaniemi I, Knight PG, Charlton HM. The effect of a null mutation in the folliclestimulating hormone receptor gene on mouse reproduction. Endocrinology. 2000;141:1795-803.

[ 5] Dierich A, Sairam MR, Monaco L, Fimia GM, Gansmuller A, LeMeur M, Sassone-Corsi P. Impairing follicle-stimulating hormone (FSH) signaling in vivo: targeted disruption of the FSH receptor leads to aberrant gametogenesis and hormonal imbalance. Proc Natl Acad Sci U.S.A. 1998;95:13612-7.

[6] Kumar TR, Wang Y, Lu N, Matzuk MM. Follicle stimulating hormone is required for ovarian follicle maturation but not male fertility. Nat Genet. 1997;15:201-4.
[7] Chang C, Chen YT, Yeh SD, Xu Q, Wang RS, Guillou F, Lardy $\mathrm{H}$, Yeh S. Infertility with defective spermatogenesis and hypotestosteronemia in male mice lacking the androgen receptor in Sertoli cells. Proc Natl Acad Sci U S A. 2004;101:6876-6881.

[ 8] De Gendt K, Swinnen JV, Saunders PT, Schoonjans L, Dewerchin M, Devos A, Tan K, Atanassova N, Claessens F, Lecureuil C, Heyns W, Carmeliet P, Guillou F, Sharpe RM, Verhoeven G. A Sertoli cell-selective knockout of the androgen receptor causes spermatogenic arrest in meiosis. Proc Natl Acad Sci U S A. 2004;101:1327-1332.

[9] Holdcraft RW, Braun RE. Androgen receptor function is required in Sertoli cells for the terminal differentiation of haploid spermatids. Development 2004;131:459-467.

[10] Yeh S, Tsai MY, Xu Q, Mu XM, Lardy H, Huang KE, Lin H, Yeh SD, Altuwaijri S, Zhou X, Xing L, Boyce BF, Hung MC, Zhang S, Gan L, Chang C. Generation and characterization of androgen receptor knockout (ARKO) mice: an in vivo model for the study of androgen functions in selective tissues. Proc Natl Acad Sci U S A. 2002;99:13498-503.

[11] Zhang FP, Pakarainen T, Poutanen M, Toppari J, Huhtaniemi I. The low gonadotropinindependent constitutive production of testicular testosterone is sufficient to maintain spermatogenesis. Proc Natl Acad Sci U S A. 2003;100:13692-7.

[12] Liu JP, Baker J, Perkins AS, Robertson EJ, Efstratiadis A. Mice carrying null mutations of the genes encoding insulinlike growth factor I (Igf-1) and type 1 IGF receptor (Igflr). Cell. 1993;75:59-72.

[13] Oshima M, Oshima H, Taketo MM. TGF-beta receptor type II deficiency results in defects of yolk sac hematopoiesis and vasculogenesis. Dev Biol. 1996;179:297-302.

[14] Tessarollo L. Pleiotropic functions of neurotrophins in development. Cytokine Growth Factor Rev. 1998;9:125-37.

[15] Chandrashekar V, Zaczek D, Bartke A. The consequences of altered somatotropic system on reproduction. Biol Reprod. 2004; 71:17-27.

[16] Besmer P, Manova K, Duttlinger R, Huang EJ, Packer A, Gyssler C, Bachvarova RF. The kit-ligand (steel factor) and its receptor c-kit/W: pleiotropic roles in gametogenesis and melanogenesis. Dev Suppl. 1993:125-37.

[17] Meng X, Lindahl M, Hyvonen ME, Parvinen M, de Rooij DG, Hess MW, Raatikainen-Ahokas A, Sainio K, Rauvala H, Lakso M, Pichel JG, Westphal H, Saarma M, Sariola H. Regulation of cell fate decision of undifferentiated spermatogonia by GDNF. Science. 2000;287:1489-93.

[18] Kierszenbaum AL. Mammalian spermatogenesis in vivo and in vitro: a partnership of spermatogenic and somatic cell lineages. Endocrine Rev. 1994;15:116-134.

[19] Hue D, Staub C, Perrard-Sapori MH, Weiss M, Nicolle JC, Vigier M, Durand P. Meiotic differentiation of germinal cells in three-week cultures of whole cell population from rat seminiferous tubules. Biol Reprod. 1998;59:379-387.

[20] Marret C, Durand P. Culture of porcine spermatogonia: effects of purification of the germ cells, extracellular matrix and fetal calf serum on their survival and multiplication. Reprod Nutr Dev. 2000;40:305-19.

[21] Weiss M, Vigier M, Hue D, Perrard-Sapori MH, Marret C, Avallet O, Durand P. Pre- and postmeiotic expression of male germ cell-specific genes throughout 2-week cocultures of rat germinal and Sertoli cells. Biol Reprod. 1997;57:68-76.

[22] Staub C, Hue D, Nicolle JC, Perrard-Sapori MH, Segretain D, Durand $\mathrm{P}$. The whole meiotic process can occur in vitro in untransformed rat spermatogenic cells. Exp Cell Res. 2000;260:85-95.

[23] Perrard MH, Hue D, Staub C, Le Vern Y, Kerboeuf D, Durand P. Development of the meiotic step in testes of pubertal rats: comparison between the in vivo situation and under in vitro conditions. Mol Reprod Dev. 2003;65:86-95. 
[24] Vigier M, Weiss M, Perrard MH, Godet M, Durand P. The effects of FSH and of testosterone on the completion of meiosis and the very early steps of spermiogenesis of the rat: an in vitro study. J Mol Endocrinol. 2004;33:729-42.

[25] Abel MH, Baker PJ, Charlton HM, Monteiro A, Verhoeven G, De Gendt K, Guillou F, O'Shaughnessy PJ. Spermatogenesis and sertoli cell activity in mice lacking Sertoli cell receptors for follicle-stimulating hormone and androgen. Endocrinology. 2008;149:3279-85.

[26] Damestoy A, Perrard MH, Vigier M, Sabido O, Durand P. Transforming growth factor beta-1 decreases the yield of the second meiotic division of rat pachytene spermatocytes in vitro. Reprod Biol Endocrinol. 2005;3:22.

[27] Perrard MH, Vigier M, Damestoy A, Chapat C, Silandre D, Rudkin BB, Durand P. Betanerve growth factor participates in an auto/paracrine pathway of regulation of the meiotic differentiation of rat spermatocytes. J Cell Physiol. 2007;210:5162.

[28] Ingman WV, Robertson SA. Transforming growth factorbetal null mutation causes infertility in male mice associated with testosterone deficiency and sexual dysfunction. Endocrinology. 2007;148:4032-43.

[29] Teerds KJ, Dorrington JH. Localization of transforming growth factor beta 1 and beta 2 during testicular development in the rat. Biol Reprod. 1993;48:40-5.

[30] Godet M, Sabido O, Gilleron J, Durand P. Meiotic progression of rat spermatocytes requires mitogen-activated protein kinases of Sertoli cells and close contacts between the germ cells and the Sertoli cells. Dev Biol. 2008:315:173-88.

[31] Winterhager E, Pielensticker N, Freyer J, Ghanem A, Schrickel JW, Kim JS, Behr R, Grummer R, Maass K, Urschel S, Lewalter T, Tiemann K, Simoni M, Willecke K. Replacement of connexin 43 by connexin 26 in transgenic mice leads to dysfunctional reproductive organs and slowed ventricular conduction in the heart. BMC Dev Biol. 2007;7:26.

[32] Godet M, Damestoy A, Mouradian S, Rudkin BB, Durand P. Key role for cyclindependent kinases in the first and second meiotic divisions of rat spermatocytes. Biol Reprod. 2004;70:1147-52.

[33] Ortega S, Prieto I, Odajima J, Martin A, Dubus P, Sotillo R, Barbero JL, Malumbres M, Barbacid M. Cyclin-dependent kinase 2 is essential for meiosis but not for mitotic cell division in mice. Nat Genet. 2003;35:25-31.

[34] Fouchécourt S, Godet M, Sabido O, Durand P. Glial cell-linederived neurotropic factor and its receptors are expressed by germinal and somatic cells of the rat testis. $J$ Endocrinol. 2006;190:59-71.

[35] Creemers LB, Meng X, den Ouden K, van Pelt AM, Izadyar F, Santoro M, Sariola H, de Rooij DG. Transplantation of germ cells from glial cell line-derived neurotrophic factoroverexpressing mice to host testes depleted of endogenous spermatogenesis by fractionated irradiation. Biol Reprod. 2002;66:1579-84.

[36] Tadokoro Y, Yomogida K, Ohta H, Tohda A, Nishimune Y. Homeostatic regulation of germinal stem cell proliferation by the GDNF/FSH pathway. Mech Dev. 2002;113:29-39.

[37] Yomogida K, Yagura Y, Tadokoro Y, Nishimune Y. Dramatic expansion of germinal stem cells by ectopically expressed human glial cell line-derived neurotrophic factor in mouse Sertoli cells. Biol Reprod. 2003;69:1303-7.

[38] Gilleron J, Carette D, Durand P, Pointis G, Segretain D. Connexin 43 a potential regulator of cell proliferation and apoptosis within the seminiferous epithelium. Int J Biochem Cell Biol. 2009;41:1381-90.

[39] Brehm R, Zeiler M, Ruttinger C, Herde K, Kibschull M, Winterhager E, Willecke K, Guillou F, Lecureuil C, Steger K, Konrad L, Biermann K, Failing K, Bergmann M. A sertoli cell-specific knockout of connexin43 prevents initiation of spermatogenesis. Am J Pathol. 2007;171:19-31.

[40] Sridharan S, Simon L, Meling DD, Cyr DG, Gutstein DE, Fishman GI, Guillou F, Cooke PS. Proliferation of adult sertoli cells following conditional knockout of the Gap junctionalprotein GJA1 (connexin 43) in mice. Biol Reprod. 2007;76:804-12.

[41] Perrin J, Lussato D, De Meo M, Durand P, Grillo JM, Guichaoua MR, Botta A, Berge-Lefranc JL. Evolution of DNA strand-breaks in cultured spermatocytes: the Comet Assay reveals differences in normal and gamma-irradiated germ cells. Toxicol. In vitro 2007;21:81-89. 